\title{
ANALYSIS OF PREGNANCY INTENSION RISK FACTORS IN INDONESIA WITH DEMOGRAPHIC HEALTH SURVEY (DHS) IN 2017
}

\author{
Nida Luthfina \\ Faculty of Public Health, Universitas Airlangga, 60115 Surabaya, East Java, Indonesia \\ Corresponding Author: Nida Luthfina \\ E-mail: nida.luthfina-2016@fkm.unair.ac.id
}

\begin{abstract}
The pregnancy intention can be divided into two, namely the desired pregnancy and unwanted pregnancy/Kehamilan Tidak Diinginkan (KTD). Unwanted pregnancy can cause negative impacts on the mother, such as not carrying out antenatal care (ANC) and abortion. Besides, babies born from KTD are more at risk of experiencing low birth weight and not getting breast milk/Air Susu Ibu (ASI) from their mothers. Therefore, the risk factors of pregnancy intention need to be known to prevent the incidence of KTD in Indonesia. This study analyzes the risk factors for pregnancy intention in Indonesia, such as maternal age, parity, sex of the baby born, mother's work status, education level, type of area of residence, family economy, and history of contraceptive use or family planning/Keluarga Berencana (KB). The research design was cross-sectional with analysis using logistic regression statistical tests. This study used secondary data from the 2017 Demographic Health Survey (DHS) with 14,778 subjects. The results of this analysis are the risk factors for pregnancy intention in Indonesia, namely the age of the mother ( $\mathrm{p}$-value $=0,000$ and $\mathrm{OR}=1.403$ ), parity ( $\mathrm{p}$-value $=0,000$ and $\mathrm{OR}=2,860$ ), the type of area of residence ( $\mathrm{p}$-value $=0,000$ and $\mathrm{OR}=1,518$ ) and history of use of family planning ( $\mathrm{p}$-value $=0.000$ and $\mathrm{OR}=$ 0.711). The risk of adverse events is greater in mothers aged $<20$ years and $>35$ years, parity more than 3 , residing in urban areas, and having a history of using family planning. There is no significant relationship between the sex of the baby, the mother's employment status, education level, and family economy on pregnancy intention.
\end{abstract}

Keywords: Pregnancy intention, Unintended pregnancy, Indonesia, Risk factors

\begin{abstract}
ABSTRAK
Intensi kehamilan dapat dibagi menjadi dua, yaitu kehamilan yang diinginkan dan kehamilan yang tidak diinginkan (KTD). Kehamilan tidak diinginkan (KTD) dapat menyebabkan dampak negatif pada ibu seperti tidak melaksanakan antinatal care (ANC) dan menggugurkan kandungannya. Selain itu, bayi yang lahir dari KTD lebih berisiko untuk mengalami berat badan lahir rendah serta tidak mendapatkan air susu ibu (ASI) dari ibunya. Oleh karena itu, faktor risiko dari intensi kehamilan perlu diketahui sehingga dapat mencegah kejadian KTD di Indonesia. Penelitian ini menganalisis faktor risiko intensi kehamilan di Indonesia seperti usia ibu, paritas, jenis kelamin bayi yang dilahirkan, status bekerja ibu, tingkat pendidikan, jenis kawasan tempat tinggal, ekonomi keluarga dan riwayat penggunaan kontrasepsi atau keluarga berencana (KB). Desain penelitian yang dipakai adalah cross sectional dengan analisis univariabel dan bivariabel menggunakan uji statistik regresi logistik. Penelitian ini menggunakan data sekunder Demographic Health Survey (DHS) tahun 2017 dengan 14.778 subjek. Hasil dari analisis ini adalah faktor risiko dari intensi kehamilan di Indonesia yaitu usia ibu (nilai $\mathrm{p}=0,000$ dan $\mathrm{OR}=1,403$ ), paritas (nilai $\mathrm{p}=0,000$ dan $\mathrm{OR}=2,860$ ), jenis kawasan tempat tinggal (nilai $\mathrm{p}=0,000$ dan $\mathrm{OR}=$ 1,518 ) dan riwayat penggunaan $\mathrm{KB}$ (nilai $\mathrm{p}=0,000$ dan $\mathrm{OR}=0,711$ ). Risiko KTD lebih besar terjadi pada ibu usia <20 tahun dan >35 tahun, paritas lebih dari 3, bertempat tinggal di kawasan urban dan punya riwayat menggunakan KB. Tidak ada hubungan yang signifikan antara jenis kelamin bayi, status pekerjaan ibu, tingkat pendidikan dan ekonomi keluarga terhadap intensi kehamilan.
\end{abstract}

Kata kunci: Intesi Kehamilan, Kehamilan tidak diinginkan (KTD), Indonesia, Faktor risiko

\section{INTRODUCTION}

The pregnancy intention can be divided into two, namely, unwanted pregnancy/Kehamilan Tidak Diinginkan (KTD) and desired pregnancy. Unintended pregnancy or unwanted pregnancy is the timeliness of pregnancy incidence because it develops when it is not expected either at conception (occurs when no child is wanted anymore) or is mistimed. Mistimed is pregnancy at a time that is earlier than the expected period. A pregnancy that you wish to 
(intended) is pregnancy at the expected time or after the expected time (due to infertility or other difficulty getting pregnant) (Buttaro et al., 2019).

The prevalence of adverse events worldwide varies from $5.5 \%$ in the Kyrgyz Republic to $60.0 \%$ in Colombia and Peru. The average of adverse events in the 36 low to middle-income countries is $24.9 \%$ (Bellizzi et al., 2020). KTD research in developed and developing countries shows that these countries' two levels have experienced different decreases. Developed countries experienced a decline in UP by $30 \%$ while developing countries only 16\% during 2010-2014 (Bearak et al., 2018).

Unwanted pregnancies in Indonesia in 2012-2017 have increased slightly. Unwanted pregnancy in 2012 was $14 \%$, while in 2017 it was $15 \%$. The increase occurred in mistimed pregnancies in 20122017, namely 1\% (National Population and Family Planning Agency, 2013) (National Population and Family Planning Agency, 2018).

Unwanted pregnancies tend to trigger the mother to do a bad behavior and risk health for both the mother and the baby (Buttaro et al., 2019). Unwanted pregnancy makes the mother potentially not doing antenatal care (ANC) 1.79 times compared to mothers without UP (Dini, Riono and Sulistiyowati, 2016). Unwanted pregnancy can also have an impact on the baby's birth weight. Babies of mothers who have KTD are more likely to have low birth weight (LBW), 1.27 times higher than babies of mothers without KTD (Nurcahyani and Trihandini, 2013). Mothers who experience KTD tend not to breastfeed immediately because the milk does not come out (Nawati and Nurhayati, 2018).

Unwanted pregnancy can encourage women to abort the uterus. $43 \%$ of unwanted pregnancies in the United States end in abortion (Finer and Zolna, 2011). Research in India also states that nearly half of unwanted pregnancies are aborted, and $73 \%$ of abortions are performed with non-medical care(Singh et al., 2018). The number of pregnancies that ended in abortion in Southeast Asia in 2010-2014 was 27\% (Sedgh et al., 2016).

Indonesia itself has strict regulations against abortion. Abortion is not permitted unless there is an indication of the mother and baby's medical emergency and for the victim of rape (Law of the Republic of Indonesia Number 36 of 2009 concerning Health). Unsafe abortion is significantly higher in countries with strict abortion laws (Ganatra et al., 2017). Unsafe abortion can increase the likelihood of complications and death. $7.9 \%$ of maternal deaths globally are due to abortion (Say et al., 2014).

Unwanted pregnancy can cause the mother not to pay attention to prenatal care and take time to receive her baby (Nawati and Nurhayati, 2018). One of the treatments for pregnancy is ANC, which affects the baby's birth weight (Sari, Suroyo, and Fitria, 2019). Baby birth weight affects children's development and growth under five (Khayati and Sundari, 2019). KTD also harms the quality of life and decreases the female workforce's efficiency (Yazdkhasti et al., 2015). This fact shows that UP must be prevented so that babies and mothers can get a better quality of life.

The risk factors for adverse events are varied and quite numerous. Unwanted Pregnancy can be related to education level factors, economy, type of area of residence, marital status, number of children ever born, the time between pregnancies, and age (Anggraini et al., 2018). Unwanted pregnancy is also associated with risk factors for the age of women who work, with more than five children, and women's perceptions of the number of children being higher than ideal (Mohamed et al., 2019).

Unwanted pregnancy can be avoided if the risk factors for pregnancy intent are known. Knowledge of risk factors for pregnancy intention can be the basis for interventions to prevent adverse events. Therefore, this study is vital to analyze the risk factors for pregnancy intention in Indonesia using the 2017 Demographic Health Survey (DHS) data. Knowing the intention risk factors can be used to make health programs for couples of childbearing age and adolescents.

\section{METHODS}

\section{Data Source}

This study used a cross-sectional research design and used secondary data. The data source used is secondary data from the 2017 Demographic Health Survey (DHS). 


\section{Population and Inclusion Criteria}

This study examined the mothers who gave birth from 2017 to the previous five years from a 2017 DHS sample throughout Indonesia. This study used 14,778 subjects who had met the research requirements.

\section{Variable}

This study has one dependent variable: pregnancy intention, namely unwanted pregnancy and the desired pregnancy. Meanwhile, the independent variables are the mother's age, parity, sex of the baby born, mother's work status, education level, type of residence area, family economy, and history of using contraception or family planning/Keluarga Berencana (KB).

The risk factors for maternal age are divided into two categories, namely $<20$ years and $>35$ years and $20-35$ years. There are two risk factors for the sex of babies born, namely girls and boys. Parity risk factors are divided into two, namely parity $>3$ and parity $1-3$. The risk factors for the working status of mothers are divided into two, namely unemployment and work. The mothers' education level's risk factors are divided into low education (not attending school, last education was elementary school or junior high school/equivalent) and higher education (previous education was high school/equivalent or college).

The risk factors for the type of residential area are urban and rural. Family economic risk factors are divided into two, namely middle to lower and middle to upper. According to DHS 2017, economic classification is based on the ownership of certain objects such as televisions and motorized vehicles, materials for house construction, and types of access to clean water and sanitation. Then the data is assessed and divided into five groups in order of the poorest to the richest. Groups 1-3 are classified as middle to lower and groups 4-5 middle and above. Risk factors for using family planning history are divided into two, namely using and not using.

\section{Data Analysis}

The data obtained from the 2017 DHS were analyzed univariably and bivariate. The univariable analysis describes each independent variable's frequency in the group experiencing adverse events and those experiencing a desired pregnancy. Bivariable analysis using logistic regression statistical tests was studied with $\alpha=$ 0.05 and $95 \%$ confidence level (CI) to determine the relationship and the magnitude of the relationship between adverse events and risk factors.

\section{RESULT}

Unwanted pregnancies in Indonesia accounted for $17 \%(2,561)$ of 14,778 . Meanwhile, $83 \%(12,262)$ were pregnancies that were desired (table 1).

Table 1 also describes the distribution of risk factors. The incidence of adverse events was higher in subjects aged 20-35 or considered suitable for pregnancy. UP was also found more in mothers with parity 1-3. Mothers with low education found many incidents of Unwanted pregnancy. Unwanted pregnancy occurred almost equally in both sexes of babies, girls and boys, with a difference of $4.8 \%$. Th e incidence of Unwanted pregnancy was almost evenly distributed among mothers with working and non-working status and only a difference of $8.8 \%$. The incidence of Unwanted pregnancy is more frequent in mothers who live in urban areas than those who live in rural areas. Unwanted pregnancy are more common in families with middle to lower economies. Unwanted pregnancy was also more common in families with a history of family planning use (table 1).

Some significant risk factors for pregnancy intention in Indonesia are maternal age $(\mathrm{p}=0.000, \mathrm{OR}=1.403)$, parity $(\mathrm{p}$ $=0.000, \mathrm{OR}=2.860)$, type of residence $(\mathrm{p}=$ $0.000, \mathrm{OR}=1.518)$ and history of use. KB (p $=0.000, \mathrm{OR}=0.711)$. Meanwhile, the education factor, the sex of the baby, the mother's work status and the family economy did not have a significant relationship (table 2).

The results of logistic regression analysis of risk factors that were significantly related to intention were maternal age $(\mathrm{OR}=$ $1.403)$, parity $(\mathrm{OR}=2.860)$, type of residence $(\mathrm{OR}=1.518)$, and use of family planning (OR $=0.711)$ (table 2). 
Table 1. Distribution of Risk Factors Intention of Pregnancy

\begin{tabular}{|c|c|c|c|c|c|}
\hline \multirow[t]{2}{*}{ Risk Factors } & \multicolumn{2}{|c|}{$\begin{array}{l}\text { Unwanted } \\
\text { Pregnancy }\end{array}$} & \multicolumn{2}{|c|}{ Pregnancy Desirable } & \multirow[t]{2}{*}{ Amount } \\
\hline & $\mathbf{n}$ & $\%$ & $\mathbf{n}$ & $\%$ & \\
\hline Distribution of pregnancy & 2.561 & 17.0 & 12.262 & 83.0 & 14.778 \\
\hline \multicolumn{6}{|l|}{ Mother's Age } \\
\hline$<20$ and $>35$ years & 1.047 & 41.6 & 3.194 & 26.0 & 4.241 \\
\hline 20-35 years & 1.469 & 58.4 & 9.068 & 74.0 & 10.537 \\
\hline \multicolumn{6}{|l|}{ Parity } \\
\hline$>3$ & 850 & 33.8 & 1.714 & 14.0 & 2.564 \\
\hline $1-3$ & 1.666 & 66.2 & 10.548 & 86.0 & 12.214 \\
\hline \multicolumn{6}{|l|}{ Gender of Baby } \\
\hline Women & 1.197 & 47.6 & 5.985 & 48.8 & 7.182 \\
\hline Man & 1.319 & 52.4 & 6.277 & 51.2 & 7.596 \\
\hline \multicolumn{6}{|l|}{ Mother's Work Status } \\
\hline Does not work & 1.123 & 44.6 & 5.710 & 46.6 & 6.833 \\
\hline Work & 1.393 & 55.4 & 6.552 & 53.4 & 7.945 \\
\hline \multicolumn{6}{|l|}{ Level of education } \\
\hline Low & 2.087 & 82.9 & 10.162 & 82.9 & 12.249 \\
\hline High & 429 & 17.1 & 2.100 & 17.1 & 2.529 \\
\hline \multicolumn{6}{|l|}{ Type of Residential Area } \\
\hline Urban & 1.435 & 57.0 & 5.875 & 47.9 & 7.310 \\
\hline Rural & 1.081 & 43.0 & 6.387 & 52.1 & 7.468 \\
\hline \multicolumn{6}{|l|}{ Family Economy } \\
\hline Middle down & 1.578 & 62.7 & 8.028 & 65.5 & 9.606 \\
\hline Intermediate and above & 938 & 37.3 & 4.234 & 34.5 & 5.172 \\
\hline \multicolumn{6}{|l|}{ KB Usage History } \\
\hline Do not use & 597 & 23.7 & 3.726 & 30.4 & 4.323 \\
\hline Use & 1.919 & 76.3 & 8.536 & 69.6 & 10.455 \\
\hline
\end{tabular}

Table 2. Bivariable Logistic Regression Analysis of Risk Factors for Pregnancy Intention

\begin{tabular}{lccccc}
\hline \multicolumn{1}{c}{ Risk Factors } & B & p value & OR & LL-UL (CL 95\%) & $\begin{array}{c}\text { Relationship } \\
\text { Description }\end{array}$ \\
\hline Mother's Age & 0.338 & 0.000 & 1.403 & $1.269-1.550$ & Meaningful \\
Parity & 1.051 & 0.000 & 2.860 & $2.564-3.190$ & Meaningful \\
Gender of Baby & -0.035 & 0.435 & 0.965 & $0.884-1.055$ & Meaningless \\
Mother's Work Status & -0.002 & 0.957 & 0.998 & $0.911-1.093$ & Meaningless \\
Level of education & -0.099 & 0.127 & 0.906 & $0.798-1.028$ & Meaningless \\
Type of Residential Area & 0.418 & 0.000 & 1.518 & $1.379-1.672$ & Meaningful \\
Family Economy & -0.024 & 0.654 & 0.976 & $0.880-1.084$ & Meaningless \\
KB Usage History & -0.341 & 0.000 & 0.711 & $0.642-0.788$ & Meaningful \\
\hline
\end{tabular}

\section{DISCUSSION}

The analysis results show a significant relationship with risk factors maternal age, parity, type of area of residence, and history of use of family planning with pregnancy intentions. Then, there was no significant relationship between the risk factors for the sex of the baby, the mother's employment status, the level of education, and the family economy with the intention of pregnancy. 


\section{Mother's Age}

Maternal age has a significant relationship with pregnancy intention in Indonesia. Mothers who are too young or too old have a greater chance of experiencing Unwanted pregnancy 1,403 than those aged 20-35.

This study is in line with a study using secondary data from Riskesdas in 2013, which stated that the mother's age at pregnancy was related to the incidence of unwanted pregnancy intentions, with OR $=3.55$ for mothers aged 3654. This result means that mothers with old age are 3.55 times more likely to experience adverse events (Saptarini and Suparni, 2016). This result is in line with research conducted in the State of Tanzania, which revealed that mothers aged $<20$ years were more likely to experience adverse events than those aged 2034. The right age of mothers (20-34 years) has a $47 \%$ lower chance of experiencing KTD than mothers aged $<20$ years (Exavery et al., 2014).

The mother who is still in the adolescent stage (too young) results in the reproductive organs not ready for childbirth. Young mothers also tend to be psychologically unstable (Mardjan, 2016). Pregnancy outside of marriage in adolescents also tends to become UP (Amalia and Azinar, 2017).

Age $>35$ years is the age range with a high risk of pregnancy complications and childbirth (Lusiana, Andriyani, and Megasari, 2015). Pregnancy at old age for some mothers is also an embarrassment because they are still pregnant at that age (Hidayati, 2014).

Maternal age who is in the 20-35 year range has a lower chance of developing KTD. This condition can be due to the health risks faced during pregnancy, childbirth, and childbirth at this age, such as a lower likelihood of experiencing anemia (Rizkah and Mahmudiono, 2017) and also a lower incidence of preeclampsia than mothers aged $<20$ and $>$ 35 years (Kurniasari and Arifandini, 2015). Women in this age range are still expecting a pregnancy. This fact follows research conducted in Surabaya which states that mothers aged 20-30 years prefer non-longterm contraceptive methods because maternal fertility returns faster if they want to have children immediately (Sumartini and Indriani, 2017).

\section{Parity}

There is an association between parity and pregnancy intention, where parity> 32.860 times the risk of adverse events. The results of other research on family planning acceptors in the Pemalang Regency also stated that parity is a significant risk factor for the incidence of unwanted pregnancy intention with a p-value of 0.009 (Apriliana, Maftuchah, and Nurhudhariani, 2016). Another study in Tanzania explained that parity was significantly associated with the incidence of adverse events where mothers who had parity of four or more were more likely to experience unwanted and mistimed pregnancies. Respectively, 1.76 and 2.65 were higher than women who were pregnant once (Exavery et al., 2014).

High parity is a risk factor for the majority of pregnancy complications. Parity can increase the likelihood of experiencing postpartum hemorrhage (Lusiana, Andriyani, and Megasari, 2015). High parity is also a risk factor for performing cesarean surgery (Siregar and Elida, 2020). High parity can also increase economic spending to support existing children (Kusmanto, 2013). Women of childbearing age who already have enough children, namely around 2-3, also do not want to get pregnant again (Kusumawati, Kurniawati, and Pratiwi, 2018).

\section{Type of Residential Area}

There is a significant relationship between pregnancy intention and the type of area of residence. Living in urban or urban areas has 1.518 times higher risk of experiencing adverse events than living in rural or rural areas.

This result is supported by other similar research using the 2012 IDHS data, which states that the incidence of KTD with the area of residence is significantly related and more exist in urban than in rural areas (Anggraini et al., 2018). Women living in rural areas are less prone to experiencing adverse events, according to research conducted in India (Dixit, Ram, and Dwivedi, 2012).

Couples in urban blood tend to have lower fertility rates than couples who live in rural or rural areas such as Aceh (Zulkifli, Amri, and Munawar, 2020). Urban areas tend to have higher economic pressure where children's education costs are higher 
(BPS, 2019). According to research conducted in Palembang, couples of childbearing age tend to limit the number of children as recommended by the government, namely two due to the high cost of education (Saputra and Munandar, 2018).

Free association with premarital sexual relations among adolescents is more common in urban areas than the 2012 IDHS data (Umaroh, Kusumawati, and Kasjono, 2017). Promiscuity Unmarried pregnancy that occurs in adolescents ultimately tends to become KTD (Amalia and Azinar, 2017).

\section{Contraceptive Usage History}

History of family planning with pregnancy intention in Indonesia has a significant correlation with the $\mathrm{OR}=$ value 0.711 . These results indicate that unwanted pregnancy is 0.711 times more likely to arise in mothers without $\mathrm{KB}$ than mothers who use KB. In other words, mothers with a history of $\mathrm{KB}$ history are more at risk for experiencing unwanted pregnancy.

This statement is in line with other research conducted in Indonesia, where family planning has a significant relationship with unwanted pregnancy. Mothers who use family planning are more prone to developing unwanted pregnancy than those who do not use family planning (Saptarini and Suparni, 2016). This fact can be caused by failure to use contraception or contraception that is not fulfilled (Saptarini and Suparni, 2016). Failure to use contraceptives can take the form of giving up an unknown contraceptive device, taking birth control pills at the wrong time or forgetting, and not being on schedule for injection contraception, drug interactions (Magowan, Owen and Thomson, 2014).

Mothers who do not use birth control may also be expecting a pregnancy (Gustikawati et al., 2014). This result shows that when the mother is pregnant, the pregnancy is desirable. Meanwhile, mothers who use family planning have the expectation not to get pregnant or delay pregnancy. If a pregnancy occurs while using birth control, unwanted pregnancy is prone to unwanted pregnancy because you do not expect it.

\section{Level of Education}

The risk factors for the level of education on pregnancy intention were not significantly related. Another study conducted in Kenya showed similarly that education and the incidence of KTD intention were not significantly associated (Ikamari, Izugbara, and Ochako, 2013). Another study conducted at one of the PKBI Clinics, Pemalang, had different results from this study. The article stated that the incidence of KTD was related to education with a p-value of 0.008 (Apriliana, Maftuchah, and Nurhudhariani, 2016).

Research carried out in Aceh has proven that the level of education can influence a mother's knowledge. The higher the mother's education, the increased knowledge about reproduction and sexuality (Asiah, 2009). However, information is now more easily accessible to all groups. Internet users in Indonesia have continually been increasing every year, and in 2017 it reached 54.68\% of the total population of Indonesia, with the most users in the age range 19-34 years (APJII, 2017). The internet is proven to be a source of knowledge in preventing KTD in adolescents in a study conducted in Bengkulu City (Ismiati, 2014).

Knowledge can be obtained outside of formal education. Older age can be a factor in increasing knowledge. The experience gained with age can increase the mother's knowledge. Research conducted in Indragiri Hulu District shows that understanding sexually transmitted diseases is better for older mothers than young ones (Harianti and Nurbaiti, 2016).

\section{Gender of Baby}

The sex of the baby was not significantly related to the intention of pregnancy. This result is contrary to research in Iran, which states a relationship between the baby sex in the last pregnancy with a KTD. The study shows that pregnancies with female sexes are 2.85 times more likely to experience adverse events than male babies (Afkhamzadeh et al., 2020). These conflicting results can be attributed to the cultural and cultural differences between Iran and Indonesia. There is no significant relationship between the sex of the child and the perceived value of children in rural areas (Putri, 2014). 
Couples in Indonesia tend to want more children if they have not had two sexes of children or one of their children's sexes. This fact is evidenced by research conducted in Palembang City, which states that the most influential factor in choosing the long-term contraceptive method (LTCM) is having two children (Aryati, Sukamdi, and Widyastuti, 2019).

Several customs in Indonesia prioritize boys over girls, such as in the Komering Tribe Society, but nowadays, they recognize men and women's equality. Only in rural areas who consider this culture still valid (Primary, 2017).

\section{Mother's Work Status}

There is no significant relationship between maternal work status and pregnancy intention in Indonesia. This result is supported by research in Iran that states that the mother's work status does not substantially affect the meaning of unwanted pregnancy (Cheraghi et al., 2013). This statement contradicts research in Egypt states that unwanted pregnancy is 6.16 times more likely to occur in mothers with working status to earn income than those with ideal non-working status.

Women in Indonesia have legal protection when pregnant at work. Regulations containing provisions for pregnant women workers in Indonesia are included in Law no. 13 of 2003 concerning Manpower. Article 82 paragraph 2 states that working women have the right to rest for 1.5 months respectively before and after giving birth, so that the total rest is three months. Female workers who experience a miscarriage are also entitled to rest for 1.5 months or according to the doctor/midwife's statement. Pregnant women are also not allowed to work from 23.00-07.00 if there is a doctor's statement that it is dangerous to the health and safety of the womb and itself (Law No.13 of 2003 concerning Manpower). Women who are pregnant cannot be terminated from work due to pregnancy reasons (Minister of Workers Regulation No.3 of 1989). The rules above can ensure the welfare of women during pregnancy as well as after pregnancy.

\section{Family Economy}

There is no significant correlation between the family economy and pregnancy intention in Indonesia. This result is reinforced by another study conducted in Tanzania with a p-value for the family economic status of 0.369 , so it is not related to the incidence of KTD intentions (Exavery et al., 2014). Other studies stated that the study results were contradictory, namely that the economy affected the incidence of KTD where women who had low family economic status were more prone to experiencing KTD (Ikamari, Izugbara, and Ochako, 2013). This statement because in Indonesia family planning or contraception has been provided by the government for free, such as condoms, intrauterine contraceptives, and contraceptives. Simultaneously, other contraceptives are also available free of charge, but only for the poor. With this, it is hoped that all levels of the community's economy can access family planning (Ministry of Health, Republic of Indonesia, 2013).

KTD can occur evenly in families with upper and lower-middle economies. This fact can be caused because other things can affect it. Other factors that can influence such as the age of women who work, children more than five, and women's perceptions of the number of children higher than ideal (Mohamed et al., 2019).

\section{CONCLUSIONS AND SUGGESTIONS}

\section{Conclusions}

The risk factors for pregnancy intention that have a significant relationship in Indonesia, according to the 2017 DHS data analysis, are maternal age, parity, type of area of residence, and history of contraceptive use. At the same time, risk factors that were not significantly related were the sex of the baby, the mother's work status, education level, and family economy.

\section{Suggestion}

The intention of an unwanted pregnancy can harm both the mother and the baby. The government can use information about the risk factors for unwanted pregnancy 
to make health policies. Getting married too young tends to give birth at a too young age. This group needs to be protected with short-term contraception to delay pregnancy until it is ripe for having children. Couples with high parity also need to understand the advantages of using permanent contraception, namely vasectomy, and tubectomy.

Unwanted Pregnancies are more prevalent in urban or urban areas, so that extension should be encouraged in urban areas. Family planning users who are still experiencing KTD or family planning users, in general, can be given a deeper understanding of the use of each contraceptive and how to treat it for those who use the device. This condition is done so that family planning failures can be suppressed so that KTD can be reduced.

\section{REFERENCES}

Afkhamzadeh, A., Rahmani, K., Felehgary, M., Farhadifar, F. and Faraji, O., 2020. Risk Factors for Unintended Pregnancy in Women: A Nested Case-Control Study. Shiraz E Medical Journal, 21 (1), pp. 18.

Amalia, EH and Azinar, M., 2017. Unwanted Pregnancy in Adolescents. Higeia, 1 (1), pp. 1-7.

Anggraini, K., Wratsangka, R., Bantas, K. and Fikawati, S., 2018. Factors Associated with Unwanted Pregnancy in Indonesia. PROMOTIVE: Journal of Public Health, 8 (1), pp. 27-37.

APJII, 2017. Internet User Behavior \& Penetration in Indonesia Survey 2017.

Apriliana, AK, Maftuchah and Nurhudhariani, R., 2016. The Relationship of Education and Parity with the Incidence of Unwanted Pregnancy at Family Planning Acceptors at PKBI As Sakinah, Pemalang Regency, 2014. Journal of Midwifery SMART, 3 (2), pp. 36-45.

Aryati, S., Sukamdi, S. and Widyastuti, D., 2019. Factors Affecting the Selection of Contraception Methods (Case in Seberang Ulu I District, Palembang City). Indonesian Geography Magazine, 33 (1), pp. 79-85.

Asiah, 2009. Relationship between Education
Level and Reproductive Health Knowledge for Housewives in Rukoh Village, Syiah Kuala District, Banda Aceh. Journal of Educational Biology, 1 (2), pp. 1-4.

National Population and Family Planning Agency, 2013. Indonesian Demographic and Health Survey 2012. Jakarta.

National Population and Family Planning Agency, 2018. Indonesian Demographic and Health Survey 2017. Jakarta.

Bearak, J., Popinchalk, A., Alkema, L. and Sedgh, G., 2018. Articles Global, Regional, and Subregional Trends in Unintended Pregnancy and Its Outcomes from 1990 to 2014: Estimates from A Bayesian Hierarchical Model. The Lancet Global Health, 6, pp. 380-389.

Bellizzi, S., Mannava, P., Nagai, M. and Sobel, HL, 2020. Reasons For Discontinuation of Contraception Among Women With A Current Unintended Pregnancy in 36 Low and Middle-Income Countries. Contraception, 101 (1), pp. 26-33.

BPS, 2019. National Socio-Economic Survey (SUSENAS) - Socio-Culture and Education Module (Annual), 2018.

Buttaro, TM, Bailey, PP, Cook, JS and Trybulski, J., 2019. Primary Care: Interprofessional Collaborative Practice. 6th ed. Missouri: Elsevier.

Cheraghi, P., Poorolajal, J., Moeini, B. and Cheraghi, Z., 2013. Predictors of Unintended Pregnancy Among Married Women in Hamadan, Western Iran: A Case-Control Study. Iranian Journal of Public Health, 42 (8), pp. 854-859.

Dini, LI, Riono, P. and Sulistiyowati, N., 2016. The Effect of Unwanted Pregnancy Status on Mother Behavior During Pregnancy and After Birth in Indonesia (2012 IDHS Data Analysis). Journal of Reproductive Health, 7 (2), pp. 119133.

Dixit, P., Ram, F. and Dwivedi, LK, 2012. Determinants of Unwanted Pregnancies in India Using Matched Case-Control Designs. BMC Pregnancy and Childbirth, 12 (84), pp. 1-12.

Exavery, A., Kanté, AM, Njozi, M., Tani, K., Doctor, HV, Hingora, A. and Phillips, JF, 2014. Predictors of Mistimed and 
Unwanted Pregnancies among Women of Childbearing Age in Rufiji, Kilombero, and Ulanga Districts of Tanzania. Reproductive Health, 11 (63), pp. 1-9.

Finer, LB, and Zolna, MR, 2011. Unintended Pregnancy in The United States: Incidence and Disparities, 2006. Contraception, 84 (5), pp.478-485.

Ganatra, B., Gerdts, C., Rossier, C., Johnson, BR, Tunçalp, Ö., Assifi, A., Sedgh, G., Singh, S., Bankole, A., Popinchalk, A., Bearak, J., Kang, Z. and Alkema, L., 2017. Global, Regional, and Subregional Classification of Abortions By Safety, 2010-14: Estimates From A Bayesian Hierarchical Model. The Lancet, 390 (10110), pp. 2372-2381.

Gustikawati, N., Wulandari, LPL, Duarsa, DP, Gustikawati, N., Wulandari, LPL and Duarsa, DP, 2014. Inhibiting and Supporting Factors for the Use of Implant Contraceptives in Puskesmas I Denpasar Utara. Public Health and Preventive Medicine Archive, 2 (2), pp. 181-188.

Harianti, R. and Nurbaiti, 2016. Characteristics, knowledge, and attitudes of fertile aged couples about Indragiri Hulu Regency. Journal of Reproductive Health, 7 (3), pp. 1999-209.

Hidayati, DS, 2014. Psychological Background of Anxiety in Pregnant Women Age 35 Years and Over. Scientific Journal of Applied Psychology, 02 (02), pp. 325334.

Ikamari, L., Izugbara, C. and Ochako, R., 2013. Prevalence and Determinants of Unintended Pregnancy Among Women in Nairobi, Kenya. BMC Pregnancy and Childbirth, 13 (69), pp. 1-9.

Ismiati, 2014. The Use of the Internet on Adolescent Knowledge in Preventing Unwanted Pregnancy. Journal of Health Media, 7 (1), pp. 31-36.

Indonesian Ministry of Health, 2013. Health Data and Information Window Bulletin. Ministry of Health of the Republic of Indonesia. Jakarta.

Khayati, YN and Sundari, S., 2019. The Relationship between Birth Weight and Growth and Development. Indonesian Journal of Midwifery (IJM), 2 (2), pp. 58-63.

Kurniasari, D. and Arifandini, F., 2015.
Relationship between Age, Parity and Diabetes Mellitus in Pregnancy with the Incidence of Preeclampsia in Pregnant Women in the Work Area of Puskesmas Rumbia, Central Lampung Regency, 2014. Journal of Holistic Health, 9 (3), pp. $142-150$.

Kusmanto, TY, 2013. Those Who Are Uprooted From Their Future: Sociological Analysis of Child Social Problems in Indonesia. Sawwa: Journal of Gender Studies, 8 (2), p. 225.

Kusumawati, D., Kurniawati, I. and Pratiwi, AY, 2018. Relationship between Frequency Parity and Selection of Long-Term Contraception Methods in Fertile Women Ages 15-49 Years at Bpm Ny.D Singotrunan Village, Banyuwangi Regency, 2018. Healthy, 7 (1), pp. 1-10.

Lusiana, N., Andriyani, R. and Megasari, M., 2015. Textbook of Midwifery Research Methodology. Yogyakarta:Deepublish.

Magowan, BA, Owen, P. and Thomson, A. eds., 2014. Clinical Obstetrics and Gynecology E-Book. 3rd ed. Edinburgh: Saunders Elsevier.

Mardjan, H., 2016. The Effect of Anxiety on Adolescent Primiparous Pregnancy. Jakarta: Abrori Institute.

Mohamed, EA-EB, Hamed, AF, Yousef, FMA and Ahmed, EA, 2019. Prevalence, Determinants, and Outcomes of Unintended Pregnancy in Sohag District, Egypt. Journal of the Egyptian Public Health Association, 94 (14), pp. $1-9$.

Nawati and Nurhayati, F., 2018. Impact of Unwanted Pregnancy on Pregnancy and Infant Care (Phenomenology Study) in Bogor City. Journal of Health, 9 (1), pp. 21-25.

Nurcahyani, DA and Trihandini, I., 2013. Unwanted Pregnancy and Baby Birth Weight. National Journal of Public Health, 7 (8), pp. 354-359.

Minister of Workers Regulation No. 3 of 1989 concerning the Prohibition of Termination of Employment (PHK) for female workers due to marriage, pregnancy, or childbirth.

Pratama, C., 2017. Value of Children in Indigenous Culture: The Existence of Boys in the Komering Tribe Family. An Nisa'a: Kanian Journal of Gender and 
Children, 12 (1), pp. 89-98.

Putri, CYYP, 2014. The Relationship between Perceptions of Children's Values and the Number and Sex of Children Desired in Premarital Women in Rural Areas. Journal of Biometrics and Population, 3 (1), pp. 20-27.

Rizkah, Z. and Mahmudiono, T., 2017. The Relationship Between Age, Gravida, and Work Status Against the Risk of Chronic Energy Deficiency (KEK) and Anemia in Pregnant Women. Amerta Nutrition, 1 (2), pp. 72-79.

Saptarini, I. and Suparni, 2016. Determinants of Unwanted Pregnancy in Indonesia (Secondary Data Analysis Riskesdas 2013). Journal of Reproductive Health, 7 (1), pp. 15-24.

Saputra, W. and Munandar, B., 2018. The decision to Have Children for Migrant Residents in Slum Settlements in Palembang City, South Sumatra Province. Demography Journal of Sriwijaya, 2 (1), pp. 25-39.

Sari, IP, Suroyo, RB and Fitria, A., 2019. Analysis of Determinant Factors of Mother's Behavior in Pregnancy on Baby Weight at the Simeulue Regional General Hospital in 2018. Journal of Issues in Midwifery, 3 (3), pp. 97- 119.

Say, L., Chou, D., Gemmill, A., Tunçalp, Ö., Moller, AB, Daniels, J., Gülmezoglu, AM, Temmerman, M. and Alkema, L., 2014. Global Causes of Maternal Death: A WHO Systematic Analysis. The Lancet Global Health, 2, pp. 323333.

Sedgh, G., Bearak, J., Singh, S., Bankole, A., Popinchalk, A., Ganatra, B., Rossier, C., Gerdts, C., Tuncalp, O., Johnson Jr, BR, Johnston, HB and Alkema, L., 2016. Abortion Incidence Between 1990 and 2014: Global, Regional, and
Subregional Levels and Trends. Lancet, 388 (10041), pp. 258-267.

Singh, S., Shekhar, C., Acharya, R., Moore, AM, Stillman, M., Pradhan, MR, Frost, JJ, Sahoo, H., Alagarajan, M., Hussain, R., Sundaram, A., Vlassoff, M., Kalyanwala, S. and Browne, A., 2018. The Incidence of Abortion and Unintended Pregnancy in India, 2015. The Lancet Global Health, 6 (1), pp.e111 - e120.

Siregar, SMF and Elida, S., 2020. Factor Analysis of Mothers Who Have Normal Childbirth Experiencing the Risk of Caesarean Section. Journal of Midwifery Maternity, 4 (2).

Sumartini, S. and Indriani, D., 2017. The influence of the desire of fertile age couples (Pus) in long-term contraceptive methods. Journal of Biometrics and Population, 5 (1), pp. 27-34.

Umaroh, AK, Kusumawati, Y. and Kasjono, HS, 2017. The Relationship Between Internal and External Factors and Adolescent Premarital Sexual Behavior in Indonesia. Andalas Public Health Journal, 10 (1), pp. 65-75.

Law of the Republic of Indonesia Number 36 of 2009 concerning Health.

UU no. 13 of 2003 concerning Manpower.

Yazdkhasti, M., Pourreza, A., Pirak, A. and Abdi, F., 2015. Unintended Pregnancy and Its Adverse Social and Economic Consequences On Health System: A Narrative Review Article. Iranian Journal of Public Health, 44 (1), pp. 12 21.

Zulkifli, Amri, and Munawar, E., 2020. Fertility Analysis in Aceh Province. Darussalam Journal of Economic Perspectives, 6 (1), pp. 54-71. 